\title{
Satuan Bahasa Penanda Soal Cerita Yang Dikerjakan dengan Mencari KPK dan FPB
}

\author{
Agus Edy Laksono, S.S., M.Hum. \\ Fakultas Teknologi Informasi dan Komunikasi, Universitas Semarang \\ email: agus@usm.ac.id
}

\begin{abstract}
Abstrak
Soal cerita yang harus dikerjakan dengan mencari KPK dan FPB dari beberapa bilangan pertama kali disampaikan dengan langsung menanyakan berapakah KPK dan FPB bilanganbilangan tersebut. Namun, setelah peserta didik memahami cara menemukannya, pendidik akan mengembangkan soal-soal tersebut menjadi soal cerita. Persoalannya adalah, masih ada peserta didik yang kesulitan mengerjakan soal-soal yang melibatkan keduanya. Penelitian ini bertujuan mendeskripsikan bentuk-bentuk dan kategori penanda soal cerita yang melibatkan KPK dan FPB. Data dianalisis menggunakan metode agih dengan teknik ganti sehingga hasil penelitian menunjukkan bahwa baik bentuk maupun kategori satuan bahasa penanda soal-soal cerita yang seharusnya dikerjakan dengan menemukan KPK akan berkaitan dengan waktu, sedangkan bentuk maupun kategori satuan bahasa penanda soal-soal cerita yang semestinya dikerjakan dengan mencari FPB akan berkaitan dengan jumlah/ ukuran/ kuantitas

Kata kunci: soal cerita, KPK, FPB, bentuk, kategori
\end{abstract}

\section{Pendahuluan}

Pembahasan mengenai kelipatan persekutuan terkecil (KPK) dan faktor persekutuan terbesar (FPB) dalam pembelajaran matematika sering ditemukan di SD dan SMP. KPK merupakan bilangan kelipatan terkecil yang kembar dari banyaknya bilangan tertentu, sedangkan FPB merupakan faktor persekutuan yang nilainya terbesar di antara faktor-faktor persekutuan lainnya (Yuniarto, 2009). Pembelajaran ini dapat dikaitkan dengan kehidupan sehari-hari dalam mencari waktu bersamaan suatu kegiatan serta jumlah maksimal dari suatu pembagian. Misalnya, di sebuah rumah, terdapat 3 lampu hias masing-masing menyala setiap 5, 6, dan 7 detik. Berapa detik sekali nyala ketiga lampu tersebut bersaamaan? Cara menemukan kapan nyala ketiga lampu tersebut bersamaan adalah dengan mencari KPK dari bilangan-bilangan tersebut (5, 6, dan 7). Selain itu misal ada contoh kelas A terdiri atas 50 siswa, kelas B terdiri atas 45 siswa, dan kelas C terdiri atas 60 siswa. Jika ada seseorang ingin membagi kelas tersebut menjadi kelompok yang banyaknya sama dan maksimal, orang tersebut dapat memanfaatkan FPB untuk membaginya menjadi beberapa kelompok.

Yuniati (2012) dalam penelitiannya sudah mencoba untuk menemukan metode baru dalam menemukan KPK dan FPB yang dinamainya metode PEBI. Penelitian ini mencoba menawarkan cara menemukan KPK dan FPB dalam bentuk bilangan pecahan menggunakan algoritma euclides, konsep bilangan basit (prima), dan konsep irisan pada teori himpunan. Dalam penelitiannya, Yuniati menawarkan kepada para pendidik dan peserta didik agar menyelesaikan soal KPK dan FPB dengan variatif, tetapi belum menunjukkan contoh berupa soal cerita kepada para pendidik dan peserta didik ketika menghadapi soal KPK dan FPB yang berbentuk cerita. Contoh-contoh soal yang disajikan hanya terdiri atas angka-angka, tanpa satuan bahasa. Senada dengan Yuniati (2012), penelitian serupa dilakukan oleh Ummah (2019). Dalam penelitiannya, Ummah (2019) menawarkan metode-metode lain dalam pengerjaan soal KPK dan FPB yakni dengan metode sinar $\mathrm{x}$ yang terdiri dari tiga metode yaitu metode irisan, metode pagar, dan metode excel. 
Metode-metode tersebut tidak lain merupakan alternatif untuk menyelesaikan soal yang berkaitan dengan KPK dan FPB dalam posisi siswa sudah mengetahui bahwa soal tersebut harus diselesaikan dengan KPK atau FPB. Selain itu, metode-metode tersebut adalah metode-metode yang diperkenalkan oleh guru-guru matematika, bukan bahasa.

Dalam pembelajarannya, soal matematika yang diberikan pertama kali disampaikan dengan langsung menanyakan berapakah KPK dan FPB beberapa bilangan. Namun, setelah siswa memahami cara menemukannya, pendidik akan mengembangkan soal-soal tersebut menjadi soal cerita. Soal-soal cerita tersebut merupakan sebuah cara pendidik matematika agar mampu mengajari para peserta didik memecahkan masalah sehari-hari di kehidupan mereka. Masalahmasalah ini tentunya hanya bisa diselesaikan dengan cara matematika. Persoalannya adalah, masih ada peserta didik yang kesulitan menentukan apakah mereka harus mencari KPK atau FPB ketika ada suatu soal cerita yang berkaitan dengan bilangan. Mereka bingung apakah soal cerita yang diberikan harus diselesaikan menggunakan KPK atau mungkin diselesaikan menggunakan FPB. Hal ini sangat wajar karena saat pendidik mengubah bentuk soal yang tadinya hanya terdiri atas angka menjadi angka dan satuan bahasa, peserta didik akan berpikir-lebih dalam memahami soal yang disediakan.

Penelitian ini akan mendeskripsikan bentuk-bentuk dan kategori satuan bahasa penanda soal cerita yang harus diselesaikan dengan mencari KPK dan FPB dari beberapa bilangan. Analisis terhadap satuan-satuan bahasa penanda tersebut akan dapat menunjukkan bentuk-bentuk dan kategori satuan bahasa yang digunakan oleh penulis soal sehingga dapat membantu para peserta didik menentukan apakah soal-soal cerita tersebut diselesaikan dengan mencari kelipatan atau faktor bilangan-bilangan yang tersedia.

\section{Landasan Teori}

Matematika memang identik dengan angka. Namun, ketika soal matematika dibuat berbentuk cerita, penulis soal tentu akan memanfaatkan satuan-satuan bahasa yang berbentuk afiks, kata, dan frase. Afiks, kata, dan frase tersebut dimanfaatkan pembuat soal dalam menyusun kalimat-kalimat sehingga menjadi soal cerita.

Afiks sering disebut dengan istilah imbuhan. Afiks merupakan satuan bahasa terikat, sehingga bila ditambahkan di awal, tengah, maupun akhir suatu kata yang belum mengalami proses gramatikal, kata tersebut akan berubah menjadi kata baru dan maknanya pun tentu akan berubah (Richards, 1992). Jenis-jenis afiks terbagi menjadi prefiks (awalan), infiks (sisipan), sufiks (akhiran), simulfiks (awalan terlebur), konfiks (gabungan yang permanen), imbuhan gabung, superfiks, interfiks, dan transfiks. (Robins, 1992).

Keraf. (1991) menyatakan bahwa ketika suatu kalimat dibagi-bagi menjadi satuan bahasa yang terkecil dan mengandung suatu ide, akan membentuk suatu kata. Menurut Kridalaksana (1994), berdasarkan kategorinya, kata dapat dikategorikan menjadi sepuluh macam, yaitu kata benda (nomina), kata keadaan (ajektiva), kata ganti (pronomina), kata kerja (verba), kata bilangan (numeralia), kata sandang (partikel), kata depan (preposisi), kata keterangan (adverbial), kata sambung (konjungsi), dan kata seru (interjeksi). 
Keraf (1984, p.138) juga menyatakan bahwa frasa merupakan suatu konstruksi yang terdiri atas dua kata atau lebih hingga membentuk suatu kesatuan. Rosliana (2015) juga menyebutkan bahwa frase tidak melebihi batas fungsi dalam kalimat, sehingga frase bukan klausa atau pun kalimat. Hal ini berarti dalam pembentukannya, frase tidak terdiri atas satu kata saja, tetapi dua kata, bahkan lebih. Berdasarkan komponen pembentuknya, frase dibedakan menjadi frase eksosentris dan frase endosentris (Parera, 2009, p.55). Frase endosentris terbagi atas frase endosentris koordinatif, apositif, dan atributif, sedangkan frase eksosentris terbagi atas frase eksosentris direktif dan nondirektif.

\section{Metode Penelitian}

Berdasarkan perlakuannya terhadap data yang tersedia, penelitian ini berjenis deskriptif karena mencoba mendeskripsikan atau menggambarkan kejadian-kejadian yang ada sesuai hasil observasi. Sujana \& Ibrahim (1989, p. 65) menyatakan bahwa penelitian deskriptif berusaha mendeskripsikan suatu gejala, maupun peristiwa pada masa sekarang. Gejala atau peristiwa yang diteliti sudah ada tinggal mendeskripsikan. Penelitian ini mendeskripsikan bentuk-bentuk satuan bahasa penanda soal cerita yang harus diselesaikan dengan cara mencari kelipatan persekutuan yang terkecil dan faktor persekutuan yang terbesar dari beberapa bilangan.

Data berupa satuan bahasa penanda tersebut dijaring dengan metode simak atau metode observasi. Setelah diobservasi, diberlakukan teknik simak bebas libat cakap. Data akan dianalisis dengan metode agih atau metode distribusional dengan teknik ganti. Sumber data penelitian ini ada 5 weblog yang memuat soal cerita yang berkaitan dengan kelipatan dan faktor. Penentuan sumber data ini dilakukan dengan metode acak, tanpa tujuan lain selain adanya soal cerita yang berkaitan dengan keduanya. Setelah dianalisis, data disajikan dengan metode informal, menggunakan kata-kata biasa, tanpa rumus (Kesuma, 2007).

\section{Pembahasan}

Penelitian ini berfokus pada bentuk dan kategori satuan bahasa penanda soal cerita yang penyelesaiannya melibatkan KPK dan FPB dari bilangan-bilangan yang ada. Dengan melihat satuan-satuan bahasa tersebut, peserta didik yang menjawab soal tidak perlu bingung lagi dalam menentukan soal mana yang semestinya dikerjakan dengan mencari KPK dan soal mana yang semestinya dikerjakan dengan mencari FPB.

\subsection{Bentuk Satuan Bahasa}

Hasil penelitian menunjukkan bahwa satuan bahasa penanda soal itu muncul dalam tiga bentuk, yaitu berbentuk afiks (imbuhan), kata dan frase.

\subsubsection{Afiks}

Afiks merupakan bentuk terikat/ tidak dapat berdiri sendiri dan maknanya belum dapat diidentifikasi sebelum bergabung dengan kata-kata tertentu (Ramlan, 2012, p. 53). ${ }^{1}$ Penanda soal berbentuk afiks dapat dilihat pada data berikut.

\begin{tabular}{|c|l|}
\hline KPK & \multicolumn{1}{|c|}{ FPB } \\
\hline- & ter- \\
\hline
\end{tabular}

\footnotetext{
${ }^{1}$ Ramlan. 2012. Morfologi Suatu Tinjauan Deskriptif. Yogyakarta: C.V. Karyono
} 
Afiks yang muncul terbatas pada prefiks ter-. Prefiks ter- dikombinasikan dengan kata panjang muncul pada data ke-2. Prefiks tersebut menimbulkan makna gramatikal 'paling panjang'. Pemilihan prefiks ter- tidak terlepas dari cara mengerjakan soalnya. Pengerjaan soal dengan mencari FPB dari beberapa bilangan akan menghasilkan bilangan pembagi yang terbesar yang dapat menjadi pembagi beberapa bilangan. Karena FPB merupakan bilangan pembagi yang paling besar, prefiks ter- yang bermakna paling ini muncul. Prefiks ter-ini bisa dikombinasikan dengan kata-kata lain yang maknanya menunjukkan suatu ukuran, seperti, besar, luas, atau banyak. Jadi, soal cerita yang penyelesaiannya melibatkan FPB akan memuat kata-kata seperti terpanjang, terbesar, terluas, ataupun terbanyak.

\subsubsection{Kata}

Penanda soal cerita berupa kata dapat dilihat pada data-data berikut. Kata-kata berikut sangat wajar ditemukan pada soal-soal cerita yang melibatkan bilangan.

\begin{tabular}{|l|lr|}
\hline \multicolumn{2}{|c|}{ KPK } & \multicolumn{2}{|c|}{ FPB } \\
\hline setiap, sekali, bersama, ketiga, kembali, & dibagikan, banyak, membagi, jumlah, \\
bersamaan, lagi, bersama-sama, pertama & banyaknya, maksimal, sama, sebanyak- \\
& banyaknya, tiap, dibagi, setiap \\
\hline
\end{tabular}

Sebelum menganalisis kata penanda soal yang harus dikerjakan dengan cara mencari KPK dan FPB dari beberapa bilangan, contoh soal dan pengerjaannya akan dipaparkan terlebih dahulu. Soal ini merupakan data ke-18.

1. Pak Made dan Pak Putu adalah dua satpam yang berjaga di perusahaan yang berdekatan. Setiap ... 6 hari, Pak Made ..., sedangkan Pak Putu ... setelah berjaga 8 hari. Jika ... bersamaan, berapa hari lagi ... bersamaan lagi? (D-18)

Soal tersebut merupakan soal cerita yang penyelesaiannya dapat dilakukan dengan mencari KPK dari dua atau lebih bilangan yang tersedia. Bilangan-bilangan yang dimaksud adalah bilangan 6 dan 8. KPK dari beberapa bilangan dapat dicari dengan menuliskan kelipatan dari masingmasing bilangan. Kelipatan dari bilangan 6 adalah 6, 12, 18, 24, 30, 36, 42, 48, 54, 60, 66, 72 dst., sedangkan kelipatan dari bilangan 8 adalah 8, 16, 24, 32, 40, 48, 56, 64, 72 dst. Jadi, KPK dari bilangan 6 dan 8 adalah 24. Bilangan 24 merupakan kelipatan persekutuan terkecil dari bilangan 6 dan 8 karena bilangan tersebut paling kecil dibandingan dengan kelipatan-kelipatan persekutuan yang lain. Walaupun ada bilangan kelipatan lain yang sama, yaitu bilangan 48 dan 72, 24 adalah bilangan yang terkecil di antara ketiganya. Maka, kelipatan persekutuan yang terkecil adalah 24. Itulah mengapa muncul kata-kata penanda seperti lagi, kedua, dan ketiga seperti dalam soal-soal cerita berikut.

2. Fila menyimpan uang di bank setiap 4 hari sekali dan Farah setiap 6 hari sekali. Pada awalnya mereka menabung bersama 15 Juli 2018. Pada tanggal berapa mereka menabung untuk yang kedua dan ketiga? (D-14)

3. Terdapat 3 kentongan yang masing-masing terletak di satu pos ronda dalam satu kampung. Kentongan pertama, dipukul setiap 15 menit, kentongan kedua dipukul setiap 
30 menit, dan kentongan ketiga setiap 45 menit. Jika kentongan dipukul bersamaan pukul 19,30. Pukul berapa lagi kentongan dipukul bersama? (D-22)

4. Darmiansyah pergi ke perpustakaan setiap 4 hari, Ruri setiap 6 hari. Jika mereka pergi ke perpustakaan bersama pada hari Selasa, hari apa mereka kembali ke perpustakaan bersama? (D-15)

Kata lagi, kembali, kedua dan ketiga menjadi penanda karena setelah peserta didik menemukan KPK dari beberapa bilangan, mereka harus menambahkan tanggal/ waktu semula dengan KPK bilangan-bilangan tersebut. Intensitas menambahkannya bisa dua kali atau pun tiga kali sesuai dengan permintaan pembuat soal. Ada pola sama di sana sehingga dengan mencari kelipatan persekutuan terkecilnya terlebih dahulu akan dapat ditemukan hasil sesuai permintaan pembuat soal.

Selain kata-kata tersebut, ada juga kata-kata lain yang menjadi penanda yaitu kata bersama, bersama-sama, dan bersamaan. Kata-kata tersebut berkata dasar sama, yaitu kata sama. Kata sama berarti 'berbarengan'. Kelipatan persekutuan dapat dicari dengan mencari bilangan yang sama dari suatu kelipatan dua bilangan atau lebih, sehingga kata sama dapat dijadikan penanda bahwa soal cerita tersebut dikerjakan dengan mencari KPK dari beberapa bilangan. Ketiga kata tersebut bisa juga diganti dengan kata semakna seperti berbarengan, bertemu, dan kata lain yang maknanya mirip dengan kata ulang bersama-sama. Pemilihan kata-kata tersebut tentu beralasan. Dua bilangan yang sama-sama dicari kelipatannya, suatu waktu akan menunjukkan kelipatan yang sama antara kelipatan-kelipatan keduanya. Kelipatan yang sama inilah yang menjadi cikal bakal munculnya kata-kata bersama, bersamaan, bersama-sama, berbarengan, dan bertemu.

Selain kata-kata tersebut, kata lain yang menjadi penanda adalah setiap/ tiap. Kata setiap bermakna 'tiap'. Kata tiap bermakna 'satu, saban, sewaktu-waktu'. Hal ini menunjukkan bahwa ada intensitas kegiatan yang berulang ulang. Kegiatan yang berulang ini tentu adalah kegiatan yang teratur sehingga dalam soal cerita matematika terlihat bahwa penulis soal akan membuat sebuah cerita yang di dalamnya ada seseorang yang melakukan kegiatan secara teratur, semisal seminggu sekali, sebulan sekali, atau mungkin setahun sekali. Kegiatan itu bisa bermacam-macam tergantung pilihan penulis soal. Berikut ini contoh soal cerita yang di dalamnya mengandung kata setiap/ tiap.

5. Fila menyimpan uang di bank setiap 4 hari sekali dan Farah setiap 6 hari sekali. Pada awalnya mereka menabung bersama 15 Juli 2018. Pada tanggal berapa mereka menabung untuk yang kedua dan ketiga? (D-14)

Kata setiap tampak dikombinasikan dengan kata penanda lain yaitu sekali, bersama, kedua, dan ketiga. Kata setiap menjadi penanda yang paling banyak keluar dalam soal cerita yang harus dikerjakan dengan mencari KPK dari bilangan-bilangan yang disediakan. Namun, kata setiap ini kebetulan juga ditemukan pada soal cerita yang penyelesaiannya menggunakan FPB, seperti tampak pada data berikut.

6. Humairah mengatur bunga plastik untuk dijual kembali. Ada 30 tangkai mawar dan 24 tangkai bunga bakung. Kedua bunga ditempatkan dalam vas dengan jumlah dan komposisi sama.
A. Berapa vas yang dibutuhkan Humairah?
B. Berapa jumlah setiap bunga per vas? (D-4) 
Meskipun kata setiap menjadi penanda bahwa soal cerita tersebut harus dikerjakan dengan cara mencari KPK dari beberapa bilangan, ternyata kata tersebut juga ada dalam soal cerita yang harus dikerjakan dengan cara mencari FPB dari bilangan-bilangan yang tersedia. Namun, penggunaan kata setiap pada keduanya ternyata menunjukkan perbedaan. Kata setiap yang dikombinasikan dengan angka (setiap + angka/ numeralia) menunjukkan bahwa soal tersebut harus dikerjakan dengan cara mencari KPK dari bilangan-bilangan yang tersedia. Adapun jika soal cerita yang di dalamnya mengandung kata setiap yang dikombinasikan dengan nonangka (setiap + nonangka/ nonnumeralia), cara mengerjakan soal tersebut adalah dengan cara mencari FPB dari bilangan-bilangan yang tersedia.

Pemilihan kata setiap untuk menjadi penanda dalam soal cerita yang harus dikerjakan dengan mencari KPK-nya terlebih dahulu tentu beralasan. Ketika ada soal matematika yang bukan soal cerita, para pendidik biasanya akan langsung menanyakan berapa KPK dari dua atau tiga bilangan. Kita ambil saja contoh berapa KPK antara bilangan 2 dan 5. Dengan cara menuliskan kelipatan dua bilangan tersebut, kelipatan persekutuan (sama) terkecil (KPK) dari kedua bilangan tersebut dapat ditemukan.

$$
\begin{aligned}
& 2=2,4,6,8,10,12,14,16,18,20,22,24,26,28,30, \ldots \\
& 5=5,10,15,20,25,30, \ldots
\end{aligned}
$$

Kata berulang-ulang inilah yang merujuk pada kata tiap/ setiap. Jika hanya sekali (tidak diulang-ulang) mengalikan suatu bilangan, kita hanya bisa menemukan angka 2 yang merupakan kelipatan bilangan dua. Begitu juga dengan bilangan lima. Oleh karena itu, pemilihan kata setiap yang merujuk pada perbuatan 'berulang-ulang' ini identik dengan cara mencari kelipatan dari suatu bilangan.

Adapun penjelasan kata-kata penanda soal yang harus dikerjakan dengan mencari FPB dari beberapa bilangan dapat dilihat pada contoh berikut. Soal ini merupakan data ke-1 yang penyelesaiannya dapat dilakukan dengan mencari FPB dari bilangan-bilangan yang tersedia.

\section{Icha memiliki 20 kue lapis dan 25 kue kotak. Kue tersebut dibungkus dan dibagikan} kepada teman-temannya.

\section{A. Berapa banyak paket yang dapat dibuat Icha?}

\section{B. Berapa banyak lapisan dan potongan kue per bungkus? (D-1)}

Soal cerita tersebut harus diselesaikan dengan cara mencari FPB dari beberapa bilangan yang tersedia. Dalam soal tersebut terdapat dua bilangan, yaitu 20 dan 25 . Untuk mencari FPB dari kedua bilangan tersebut maka dapat digunakan cara mencari faktor dari masing-masing bilangan. Faktor dari bilangan 20 adalah 1, 2, 4, 5, dan 10. Adapun faktor dari bilangan 25 adalah 1, 5, dan 25. Setelah melihat faktor-faktor dari kedua bilangan tersebut, tampak bilangan 1 dan 5 bersekutu/ sama. Bilangan yang terbesar antara 1 dan 5 adalah bilangan 5, sehingga FPB dari kedua bilangan tersebut adalah 5. Bilangan 1 dan 5 sama-sama dapat menjadi pembagi antara bilangan 20 dan 25 dengan hasil bilangan bulat, bukan pecahan. Adapun bilangan 2, 4, dan 10 jika menjadi pembagi angka 25, hasilnya tidak dapat menghasilkan bilangan bulat, tetapi bilangan pecahan. Oleh sebab itu, 1 dan 5 merupakan faktor-faktor yang bersekutu dari 2 bilangan. 
Bilangan 1 dan 5 akan dapat menjadi bilangan pembagi antara bilangan 20 dan 25. Hanya saja pembagi yang terbesar adalah bilangan 5. Jadi jika seseorang memiliki 2 jenis benda/ barang dengan jumlah jenis pertama (A) 20 dan jumlah jenis yang kedua (B) 25, maka akan dapat dibagikan kepada lima orang dengan masing-masing mendapatkan 4 jenis barang A dan 5 jenis barang B. Itulah mengapa kata-kata dibagikan dan membagi menjadi penanda bahwa soal tersebut harus diselesaikan dengan cara mencari FPB dari beberapa bilangan yang tersedia.

Pembagian dengan faktor yang paling besar menghasilkan pembagian yang maksimal/ terbanyak. Jadi, pembagian untuk tiap anak/ subjek selain jumlahnya sama, besarannya/ jumlahnya juga sudah maksimal atau paling banyak. Hal inilah yang menjadi cikal bakal munculnya penanda berupa kata maksimal, sebanyak-banyaknya, sama, dan jumlah.

Jika dilihat dari bentuk kata yang menjadi penanda soal, kata-kata tersebut bisa berupa kata dasar, kata berimbuhan, dan kata ulang.

\subsubsection{Kata Dasar}

Berdasarkan data yang diperoleh, kata dasar banyak ditemukan pada soal yang harus dikerjakan dengan mencari FPB dari bilangan yang tersedia. Kata dasar adalah kata yang belum mengalami afiksasi/ pengimbuhan. Penanda tersebut dapat dilihat pada kata-kata berikut.

\begin{tabular}{|l|c|}
\hline \multicolumn{1}{|c|}{ KPK } & FPB \\
\hline kembali, lagi, pertama & tiap, sama, maksimal, jumlah, banyak \\
\hline
\end{tabular}

Kata-kata dasar yang ditemukan pada soal yang harus dikerjakan dengan cara mencari KPK dari beberapa bilangan ternyata ada yang bersinonim, yaitu kata kembali dan kata lagi. Kata kembali berarti 'lagi atau balik ke tempat atau keadaan semula'. Dalam kamus, kata kembali dan lagi ini artinya sama. Suatu keadaan semula tentu melibatkan peristiwa yang terjadi pertama kali, sehingga muncul kata dasar pertama pada soal yang harus dikerjakan dengan mencari KPK dari beberapa bilangan.

Kata-kata dasar pada penanda soal yang harus dikerjakan dengan mencari FPB dari beberapa bilangan ini sebetulnya tidak jauh dari kata jumlah. Kata jumlah, tiap, sama, maksimal, dan banyak bisa dikatakan berkolokasi. Kolokasi atau sanding kata merupakan asosiasi tetap antara kata satu dengan kata yang lain (Kridalaksana, 2008, p.127). Asosiasi merupakan hubungan, jadi antara kata satu dengan kata lainnya saling berhubungan. Kalau ada satu kata yang muncul, kata yang lain kemungkinan besar juga akan muncul.

\subsubsection{Kata Berimbuhan}

Kata-kata berimbuhan juga digunakan penulis soal matematika untuk menandai bahwa soal-soal tersebut harus dikerjakan dengan mencari KPK dan FPB dari beberapa bilangan. Katakata tersebut bisa berupa prefiks, sufiks, maupun konfiks. Berikut kata-kata berimbuhan yang menjadi penanda soal cerita yang harus dikerjakan dengan mencari KPK dan FPB dari beberapa bilangan terlebih dahulu.

\begin{tabular}{|c|l|}
\hline KPK & \multicolumn{1}{|c|}{ FPB } \\
\hline setiap, sekali, bersama, ketiga, bersamaan & $\begin{array}{l}\text { dibagikan, membagi, banyaknya, dibagi, } \\
\text { setiap, }\end{array}$ \\
\hline
\end{tabular}


Penanda soal yang harus diselesaikan dengan mencari KPK dari beberapa bilangan tampak menggunakan prefiks se-, ber-, ke-, dan konfiks ber-an. Prefiks se- yang digunakan berarti 'satu', prefiks ber- yang digunakan bermakna 'melakukan sesuatu', sedangkan prefiks ke- bermakna 'urutan'. Kata setiap dan sekali merupakan kata-kata yang berkolokasi. Dalam pembuatan soalnya, penulis soal sering menuliskan kegiatan seseorang yang dilakukan setiap ... sekali. Kata bersama dan bersamaan bersinonim yang bermakna 'melakukan pekerjaan secara serentak'. Hanya saja kata bersama menggunakan awalan ber-, sedangkan kata bersamaan menggunakan afiks gabungan ber-an.

Penanda soal yang penyelesaiannya dengan mencari FPB dari beberapa bilangan tampak lebih variatif dalam penggunaan imbuhannya. Imbuhan yang digunakan meliputi prefiks, sufiks, dan konfiks. Prefiks yang digunakan bukan menggunakan prefiks ber-melainkan me- dan $d i$-. Adapun konfiks yang digunakan adalah konfiks di-kan. Sufiks yang digunakan merupakan sufiks yang terkontaminasi dengan bahasa Jawa, yaitu sufiks -nya, pada kata banyaknya. Kalau kita terjemahkan dalam bahasa Jawa, kata banyaknya menjadi akehe.

\subsubsection{Kata Ulang}

Penulis soal tampaknya juga memanfaatkan kata ulang untuk menandai bahwa soal-soal tersebut harus dikerjakan dengan mencari KPK dan FPB dari beberapa bilangan. Kata ulang yang digunakan adalah kata ulang berimbuhan. Imbuhan yang digunakan pada kata ulang penanda tersebut berupa prefiks ber- dan gabungan imbuhan se-nya. Berikut kata-kata ulang yang digunakan.

\begin{tabular}{|l|l|}
\hline \multicolumn{1}{|c|}{ KPK } & \multicolumn{1}{c|}{ FPB } \\
\hline bersama-sama & sebanyak-banyaknya \\
\hline
\end{tabular}

\subsubsection{Frase}

Selain berbentuk kata, satuan bahasa lain yang menjadi penanda adalah frase. Frase-frase tersebut terbentuk dari kata-kata yang menjadi penanda masing-masing soal. Bahkan banyak frase yang merupakan kombinasi dari kata-kata yang menjadi penanda soal yang harus dikerjakan dengan mencari KPK dan FPB dari beberapa bilangan. Berikut frase-frase yang dijadikan penanda soal yang harus dikerjakan dengan mencari KPK dan FPB dari beberapa bilangan.

\begin{tabular}{|c|c|}
\hline KPK & FPB \\
\hline $\begin{array}{l}\text { yang kedua, bersama lagi, bersamaan lagi, } \\
\text { kedua kalinya, bersama-sama lagi, pertama } \\
\text { kali, bersamaan kembali, serentak } \\
\text { bersamaan }\end{array}$ & $\begin{array}{l}\text { yang sama, jumlah maksimum, jumlah dan } \\
\text { komposisi yang sama, sama banyak, yang } \\
\text { sama banyak, secara merata dan sama } \\
\text { banyak, paling banyak secara merata, paling } \\
\text { banyak }\end{array}$ \\
\hline
\end{tabular}

Frase bersamaan lagi, bersama-sama lagi, dan bersamaan kembali merupakan frase yang artinya sama, yaitu 'berbarengan atau bertepatan', sedangkan kata lagi dan kembali juga merupakan sinonim yang berarti 'berulang seperti semula'. Jadi ketiga frase tersebut sebetulnya artinya sama, hanya terdapat variasi kata dengan memanfaatkan sinonim. Frase-frase tersebut 


\section{$\underline{\text { Laksono) }}$}

terbentuk dari kata-kata yang menandai pengerjaan soal yang harus dikerjakan dengan mencari KPK dari beberapa bilangan.

Penggunaan frase-frase tersebut merujuk pada pengerjaan soal dengan cara mencari KPK dari beberapa bilangan. Frase kedua kalinya dan pertama kali merupakan penanda soal cerita yang harus dikerjakan dengan mencari KPK dari beberapa bilangan karena dalam pengerjaan soal yang menggunakan KPK akan dapat dicari kelipatan yang sama dari beberapa bilangan, tidak hanya satu kali, tetapi bisa dua, tiga, bahkan sampai tak terhingga tergantung pembuat soal.

Dalam pembagian dua jenis barang/ benda, masing-masing orang akan mendapatkan jumlah yang sama, yaitu orang kesatu, kedua, ketiga, keempat dan kelima mendapatkan 4 jenis barang A dan 5 jenis barang B. Hal inilah yang menjadi alasan bahwa penulis soal akan memilih frase seperti panjang yang sama, sama banyak, komposisi yang sama, secara merata, dan jumlah yang sama.

Frase-frase yang dipilih oleh penulis soal terbagi menjadi frase endosentris maupun frase eksosentris. Penjenisan ini berdasarkan unsur-unsur pembentuk frase tersebut. Dalam distribusinya, frase endosentris memiliki distribusi yang sama dengan unsur-unsur pembentuknya, baik seluruh unsur maupun salah satu unsur saja (Emzir, 2012, p. 101). Adapun frase eksosentris merupakan frase yang tidak memiliki distribusi yang sama dengan semua unsurnya (Finoza, 2009, p.95).

\subsubsection{Frase Endosentris}

Penulis soal cerita ternyata juga memanfaatkan frase endosentris untuk menandai soal cerita yang harus dikerjakan dengan cara mencari KPK dan FPB dari beberapa bilangan. Frasefrase endosentris tersebut dapat dilihat pada data-data berikut.

\begin{tabular}{|l|l|}
\hline \multicolumn{1}{|c|}{ KPK } & \multicolumn{1}{|c|}{ FPB } \\
\hline bersama lagi, bersamaan lagi, kedua kalinya, & jumlah maksimum, jumlah dan komposisi \\
bersama-sama lagi, pertama kali, bersamaan & yang sama, sama banyak, paling banyak \\
kembali, serentak bersamaan & $\begin{array}{l}\text { secara merata, paling banyak, komposisi } \\
\text { yang sama }\end{array}$ \\
\hline
\end{tabular}

Frase endosentris banyak digunakan dalam penanda soal yang harus dikerjakan dengan KPK. Inti dari frase-frase penanda soal cerita yang harus dikerjakan dengan mencari KPK dari beberapa bilangan secara berturut-turut meliputi, bersama, bersamaan, kedua, bersama-sama, pertama, bersamaan, dan serentak. Dilihat dari unsur-unsur pembentuknya, frase-frase endosentris yang digunakan meliputi frase endosentris atributif dan frase endosentris apositif. frase bersama lagi, bersamaan lagi, kedua kalinya, bersama-sama lagi, pertama kali, dan bersamaan kembali merupakan frase endosentris atributif, sedangkan frase serentak bersamaan merupakan frase endosentris apositif.

Selain itu, frase endosentris juga digunakan pada penanda soal yang harus dikerjakan dengan mencari FPB dari beberapa bilangan. Frase jumlah maksimum, jumlah dan komposisi yang sama, sama banyak, paling banyak secara merata, paling banyak, dan komposisi yang sama memiliki inti secara berturut-turut jumlah, jumlah dan komposisi, sama, banyak, banyak, dan komposisi. Dilihat dari unsur-unsur pembentuknya, frase-frase endosentris yang digunakan meliputi frase endosentris atributif dan koordinatif. Frase jumlah maksimum, sama banyak, paling 
banyak secara merata, paling banyak, dan komposisi yang sama merupakan frase endosentris atributif, sedangkan jumlah dan komposisi yang sama merupakan frase atributif koordinatif.

\subsubsection{Frase Eksosentris}

Selain menggunakan frase endosentris, frase eksosentris juga digunakan oleh penulis soal cerita yang berikaitan dengan KPK dan FPB. Hanya saja penggunaannya tidak sebanyak frase endosentris.

\begin{tabular}{|l|l|}
\hline \multicolumn{1}{|c|}{ FPB } & KPK \\
\hline $\begin{array}{l}\text { yang sama, yang sama banyak, secara } \\
\text { merata dan sama banyak, }\end{array}$ & yang kedua \\
\hline
\end{tabular}

Baik soal cerita yang harus dikerjakan dengan mencari KPK maupun FPB, terdapat frase eksosentris berjenis nondirektif dan konektif. Frase eksosentris nondirektif ditandai dengan penggunaan partikel yang pada frase yang sama, yang sama banyak, dan yang kedua. Adapun frase eksosentris konektif ditandai dengan penggunaan kata sambung secara pada frase secara merata dan sama banyak.

\subsection{Kategori Satuan Bahasa Penanda Soal Cerita yang Harus Dikerjakan dengan Mencari KPK dan FPB dari Beberapa Bilangan}

Berdasarkan hasil analisis data, kategori satuan bahasa penanda soal cerita tersebut berkategori verba, numeralia, nomina, dan adverbia.

\subsubsection{Verba}

Verba merupakan kata kerja yang cirinya dapat diikuti kata dengan, baik yang menyatakan alat, keadaan, maupun penyerta (Chaer, 2000, p. 100). Verba menduduki posisi penting dalam sebuah klausa atau kalimat. Hasil analisis menunjukkan bahwa verba-verba berikut sering digunakan oleh penulis soal.

\begin{tabular}{|c|c|}
\hline KPK & FPB \\
\hline $\begin{array}{l}\text { bersama, kembali, bersamaan, bersama- } \\
\text { sama, bersama lagi, bersamaan lagi, } \\
\text { bersama-sama lagi, bersamaan kembali }\end{array}$ & dibagikan, membagi, dibagi \\
\hline
\end{tabular}

Penulis soal tampak memanfaatkan verba berkata dasar sama, yaitu kata sama. Kata sama tampak dikombinasikan dengan prefiks ber-, konfiks ber-an, kata lagi dan kata kembali. Verba yang dipilih oleh penulis soal berupa verba aktif intransitif, atau verba yang tidak membutuhkan objek. Kata-kata yang menjadi penanda tampak digabungkan dengan kata-kata lain untuk membentuk frase verba.

Adapun penanda soal yang harus dikerjakan dengan mencari FPB banyak memanfaatkan kata dasar bagi. Kata dasar tersebut diberi imbuhan me-, di-, dan di-kan. Imbuhan me- pada kata membagi berfungsi untuk membentuk kata kerja aktif. Kata kerja aktif menunjukkan subjek melakukan suatu perbuatan yaitu membagi. Adapun imbuhan di- dan di-kan akan membentuk kata kerja pasif, yaitu subjeknya dikenai pekerjaan. Penggunaan kata kerja aktif berupa aktif transitif atau kata kerja yang membutuhkan objek atau pun pelengkap. Adapun penggunaan kata kerja pasif berupa kata kerja intransitif atau kata kerja yang tidak membutuhkan objek atau pun pelengkap. 
Verba penanda soal cerita tentang FPB dapat diikuti dengan kata berkategori adverbia, seperti kata kepada dan secara, nomina persona maupun nonpersona seperti kata siswa dan pensil, serta angka atau numeralia seperti 60 atau enam puluh.

\subsubsection{Numeralia}

Numeralia atau sering disebut juga kata bilangan merupakan kata-kata yang menyatakan jumlah, nomor, urutan, atau himpunan (Chaer, 2000, p. 113). Penanda soal cerita yang ada ternyata juga berkategori numeralia. Numeralia yang digunakan dapat dilihat pada data-data berikut.

\begin{tabular}{|l|l|}
\hline \multicolumn{1}{|c|}{ KPK } & \multicolumn{1}{|c|}{ FPB } \\
\hline $\begin{array}{l}\text { setiap, ketiga, pertama, kedua kalinya, } \\
\text { pertama kali }\end{array}$ & sebanyak-banyaknya, setiap \\
\hline
\end{tabular}

Penanda-penanda soal tersebut tampak diwujudkan dalam bentuk numeralia dan frase numeralia. Numeralia yang digunakan merupakan numeralia tentu/ takrif, seperti pertama, kedua, dan ketiga. ketiganya merupakan numeralia tingkat. Numeralia pada soal cerita yang harus dikerjakan dengan mencari KPK dari beberapa bilangan digunakan untuk menyatakan suatu kegiatan. Selain numeralia tentu/ takrif, dalam soal yang menjadi penanda keduanya terdapat kata bantu bilangan yang berkategori numeralia, yaitu kata setiap.

Adapun numeralia yang digunakan dalam penanda soal cerita tentang FPB terbatas pada kata/ frase berkata dasar banyak. Kata banyak merupakan kata bilangan taktentu/ tidak takrif, tetapi menunjukkan suatu jumlah. Kata banyak dalam soal cerita penyelesaiannya dengan mencari FPB dari beberapa bilangan tampak dikombinasikan dengan nomina untuk membentuk frase nomina. Dalam soal cerita yang harus dikerjakan dengan cara mencari FPB dari beberapa bilangan, nomina yang mengikuti kata banyak dapat berupa nomina persona seperti kata tetangga, dan nomina nonpersona seperti kata pensil, paket, dan lapisan. Meskipun banyak paket, banyak lapisan, dan banyak pensil merupakan frase nomina, penanda soal cerita yang pengerjaannya dengan mencari FPB dari beberapa bilangan tersebut tetap berkategori numeralia. Kata paket, lapisan, tetangga, dan pensil tidak dapat dijadikan penanda karena kata-kata tersebut akan dapat diganti dengan kata-kata lain yang sekategori sesuai kehendak penulis soal.

\subsubsection{Nomina}

Nomina merupakan kata-kata yang dapat diikuti dengan frase yang atau yang sangat (Chaer, 2000, h. 87). Soal cerita yang harus dikerjakan dengan mencari KPK dari beberapa bilangan tidak memiliki penanda berkategori nomina. Nomina yang ditemukan dapat berupa nomina maupun frase nomina nonpersona seperti tampak pada data-data berikut.

\begin{tabular}{|c|l|}
\hline KPK & \multicolumn{1}{|c|}{ FPB } \\
\hline- & $\begin{array}{l}\text { jumlah, banyaknya, jumlah maksimum, jumlah dan } \\
\text { komposisi yang sama, komposisi yang sama }\end{array}$ \\
\hline
\end{tabular}

Nomina jumlah tampak mendominasi dalam setiap penulisan soal ceritanya. Nomina ini memang tidak berdiri sendiri, tetapi ada satuan bahasa berkategori lain yang mengikutinya sehingga membentuk frase. Namun, satuan bahasa yang mengikutinya tidak dapat dikatakan penanda karena satuan-satuan bahasa tersebut dapat diganti dengan satuan bahasa lain yang tak tentu. Satuan bahasa lain yang mengikuti nomina tersebut dapat berkategori nomina, baik persona 
maupun nonpersona seperti kata anggota, kotak kapur, anggota kelompok, dan kantong; ajektiva, seperti kata maksimum dan sama; dan adverbia, seperti kata setiap dan yang sama. Satuan bahasa yang mengikuti kata jumlah adalah ajektiva sama, yaitu jumlah ... sama.

\subsubsection{Ajektiva}

Ajektiva merupakan kata yang memberikan keterangan yang lebih khusus tentang sesuatu yang dinyatakan oleh nomina dalam kalimat. Berdasarkan perilaku semantisnya, ajektiva dapat diklasifikasikan menjadi dua, yaitu ajektiva bertaraf dan takbertaraf (Alwi, 2000). Ajektiva yang ada tampak pada data-data berikut.

\begin{tabular}{|l|l|}
\hline \multicolumn{1}{|c|}{ KPK } & FPB \\
\hline serentak & maksimal, sama, merata, ter-panjang \\
\hline
\end{tabular}

Ajektiva yang dipilih oleh penulis soal terdiri atas ajektiva-ajektiva yang bertaraf. Ajektiva serentak merupakan ajektiva bertaraf waktu yang ditemukan pada soal cerita yang harus dikerjakan dengan mencari KPK dari beberapa bilangan. Ajektiva ini menyatakan waktu yang bersamaan/ berbarengan. Dalam soal ini, ajektiva yang dipilih akan menunjukkan bahwa pelaku melakukan kegiatan bersamaan/ serentak. Adapun soal yang harus dikerjakan dengan mencari FPB dari beberapa bilangan lebih memilih ajektiva bertaraf ukuran/ jumlah, seperti maksimal, sama, dan merata. Selain itu, pemilihan afiks ter- pada kata terpanjang pun nantinya juga akan membentuk kata yang berkategori ajektiva bertaraf ukuran.

\subsubsection{Adverbia}

Adverbia merupakan kata yang berfungsi untuk memberikan keterangan pada verba, ajektiva, nomina predikatif, atau kalimat (KBBI, 2007, h.10). Adverbia yang dipilih oleh penulis soal meliputi adverbia kewaktuan dan kecaraan.

\begin{tabular}{|l|l|}
\hline \multicolumn{1}{|c|}{ KPK } & \multicolumn{1}{|c|}{ FPB } \\
\hline sekali, lagi & secara merata \\
\hline
\end{tabular}

Kata sekali dan lagi merupakan adverbia yang berkaitan dengan waktu sehingga disebut dengan adverbia kewaktuan. Kata-kata ini menjadi penanda bahwa soal yang tersedia harus dikerjakan dengan mencari KPK dari beberapa bilangan. Adapun adverbia secara yang menjadi penanda soal cerita yang harus dikerjakan dengan mencari FPB dari beberapa bilangan digabungkan dengan kata merata menjadi frase adverbia kecaraan.

\section{Simpulan}

Berdasarkan analisis terhadap bentuk dan kategori satuan bahasa penanda soal cerita yang harus dikerjakan dengan mencari KPK dan FPB dari beberapa bilangan, penulis dapat menyimpulkan hal-hal sebagai berikut:

a. Penanda soal cerita tersebut dapat diwujudkan dalam bentuk afiks/ imbuhan, kata, dan frase. Afiks yang digunakan adalah imbuhan yang bermakna 'paling' dan dikombinasikan dengan kata dasar yang menyatakan ukuran. Penggunaan kata sebagai penanda dimanfaatkan penulis soal dengan memunculkan kata dasar, kata berimbuhan, dan kata ulang berimbuhan. Adapun frase-frase yang dimanfaatkan oleh penulis soal meliputi frase endosentris dan frase eksosentris. Frase endisentris yang digunakan berupa frase 
endosentris atributif dan koordinatif, sedangkan frase eksosentris yang digunakan berupa frase eksosentris nondirektif dan konektif.

b. Kategori penanda soal-soalnya dapat berupa verba, numeralia, nomina, ajektiva, dan adverbia. Verba yang dipilih penulis soal dapat berupa verba aktif dan verba pasif. Verba aktifnya bisa berupa verba aktif transitif dan intransitif. Numeralia yang digunakan merupakan numeralia tentu/ takrif dan numeralia taktentu/ taktakrif. Nomina yang digunakan sebatas pada nomina nonpersona dan berkaitan dengan jumlah/ kuantitas. Ajektiva yang digunakan merupakan ajektiva bertaraf waktu dan bertaraf ukuran/ jumlah. Adapun adverbia yang digunakan meliputi adverbia kewaktuan dan kecaraan.

c. Soal cerita yang harus dikerjakan dengan mencari KPK dari beberapa bilangan bisa diidentifikasi dari kata, frase, dan kategori yang berkaitan dengan waktu, sedangkan soal cerita yang harus dikerjakan dengan mencari FPB dari beberapa bilangan bisa diidentifikasi dari kata, frase, dan kategori yang berkaitan dengan jumlah/ kuantitas/ ukuran.

\section{Daftar Pustaka}

Alwi, H., Dardjowidjojo, S., Lapoliwa, H. \& Moeliono, A. M. (2000). Tata Bahasa Baku Bahasa Indonesia (edisi ketiga). Jakarta: Balai Pustaka.

Alwi, H. (2007). Kamus Besar Bahasa Indonesia (edisi ketiga). Jakarta: Balai Pustaka.

Chaer, A. (2000). Semantik Bahasa Indonesia. Jakarta: Rineka Cipta.

Emzir. (2012). Metodelogi Penelitian Pendidikan Kuantitatif dan Kualitatif. Jakarta: PT Raja Grafindo Persada.

Finoza, L. (2009). Komposisi Bahasa Indonesia. Jakarta: Diksi Insan Mulia.

Keraf, Gorys. (1984). Tata Bahasa Indonesia. Ende Flores: Nusa Indah.

Keraf, Gorys. (1991). Tata Bahasa Rujukan Bahasa Indonesia untuk Tingkat Pendidikan Menengah. Jakarta: Gramedia Widiasrana Indonesia.

Kesuma, T. M. J. (2007). Pengantar (Metode) Penelitian Bahasa. Yogyakarta.

Kridalaksana, H. (2008). Kamus Linguistik. Jakarta: Gramedia Pustaka Utama.

Parera, J. D. (2009). Dasar-dasar Analisis Sintaksis. Jakarta: Erlang.

Ramlan. (2012). Morfologi: Suatu Tinjauan Deskriptif. Yogyakarta: C.V. Karyono.

Richards, J. C., Platt. J. T., \& Platt, H. (1992). Longman Dictionery of Language Teaching and Applied Linguistics. England: Longman.

Robins, R. H. (1992). Lingusitik Umum: Sebuah Pengantar. Yogyakarta: Kanisius.

Sudjana, N., \& Ibrahim. (1989). Penelitian Kualitatif dan Kuantitatif, Bandung: Sinar Baru.

Ummah, M. R. (2019). Metode Sinar-x pada Materi FPB dan KPK untuk Peserta Didik Kelas IV SD/ MI. JPM. 5(2), 73-77. Diambil dari http://riset.unisma.ac.id/index.php/jpm/article/view/2704/2664.

Verhaar, J. W. M. (2010). Asas-Asas Linguistik Umum. Yogyakarta: Gadjah Mada University Press.

Yuniarto, Y. (2009). Matematika untuk Sekolah Dasar/ Madrasah Ibtidaiyah Kelas IV. Jakarta: Pusat Perbukuan Departemen Pendidikan Nasional.

Yuniati, S. (2012). Menentukan Kelipatan Persekutuan Terkecil (KPK) dan Faktor Persekutuan Tterbesar (FPB) dengan Menggunakan Metode "Pebi". Beta, 5(2), 152-164. Diambil dari https://jurnalbeta.ac.id/index.php/betaJTM/article/view/74/81 